\title{
Urgences
}

\section{Cette phrase...}

\section{Guy Rancourt}

Numéro 15, octobre 1986

\section{Épigraphiques}

URI : https://id.erudit.org/iderudit/025340ar

DOI : https://doi.org/10.7202/025340ar

Aller au sommaire du numéro

\section{Éditeur(s)}

Urgences

\section{ISSN}

0226-9554 (imprimé)

1927-3924 (numérique)

Découvrir la revue

\section{Citer ce document}

Rancourt, G. (1986). Cette phrase... Urgences, (15), 80-80.

https://doi.org/10.7202/025340ar

Ce document est protégé par la loi sur le droit d'auteur. L'utilisation des services d'Érudit (y compris la reproduction) est assujettie à sa politique d'utilisation que vous pouvez consulter en ligne.

https://apropos.erudit.org/fr/usagers/politique-dutilisation/ 


\section{Guy Rancourt}

Il y a tant d'aurores qui n'ont pas encore lui.

Rig-Veda, dans Friedrich Nietzsche: Aurore

Cette phrase en épigraphe d'Aurore est magnifiquement belle et richement prophétique. Annonciatrice également que le meilleur de Nietzsche est encore à venir... Ne verra-t-on point luire tour à tour d'autres aurores nietzschéennes entre ce texte Aurore (1881) et Crépuscule des idoles (1889)? D'autres percées de lumière? D'autres astres luisants dans les ciels de la littérature et de la philosophie qui ont pour détonations/explosions Le gai savoir (1882), Ainsi parlait Zarathoustra (1883-85), Par-delà le bien et le mal (1886), Généalogie de la morale (1887)? Nietzsche n'a pas toujours été un voyageur porteur d'ombres. Avec toutes les aurores qui auréolent son oeuvre, ne peut-on point en convenir qu'il est aussi "porteur de Lumière", c'est-à-dire un Lucifer! Oui, Lucifer, ce Dieu-Soleil, si proche parent de Zarathoustra qu'on dirait son frère jumeau!

水水水

Dans le panthéon hindou, l'Aurore est vénérée comme la fille du Ciel et du Soleil. C'est une jeune fille qui dévoile ses beautés à ceux qu'elle aime. On la chante et l'honore parce qu'elle est le signal lumineux du retour d'Agni. Le retour du Soleil donc. L'Aurore ne serait-elle point en quelque sorte la grande annonciatrice de l'Eternel Retour si cher à Nietzsche? N'est-ce point cette Déesse, "jeune femme à la robe éclatante", qui indique aux Hindous le moment de célébrer l'"agnihotra"? Et j'entends leurs chants matutinaux d'ici:

Je t'invoque, Déesse, Aurore des lumières!

Présentons-lui l'hommage de nos chants:

elle donne le miel, elle fixe le Ciel,

elle prodigue sa splendeur, la belle Aurore.

(...)

Elle a resplendi telle une jeune fermme,

incitant tout ce qui vit à se mouvoir.

Le Feu s'est laissé enflammer par les hommes:

refoulant les ténèbres, elle a fait la lumière.

(Rig-Veda)

Nietzsche, ce si grand poète (étymologiquement "celui qui crée"), m'apparaît être le frère d'Aurore, c'est-à-dire le fils du Ciel et du Soleil - le grand repoussoir des ténèbres, le porteur de Lumière! 